\title{
Penyederhanaan Informasi Nilai Gizi Pangan Olahan Menggunakan Indeks Nutrient-Rich Foods
}

\author{
Simplification of Processed Food Nutrition Value Information \\ Using Nutrient-Rich Foods Index
}

\author{
Yogi Karsono, Nurheni Sri Palupi*, dan Dede Robiatul Adawiyah
}

Departemen Ilmu dan Teknologi Pangan, Fakultas Teknologi Pertanian, Institut Pertanian Bogor, Bogor

\begin{abstract}
Healthy diet is an effort to reduce the risk of non-communicable diseases (NCDs). The use of scientific terms on nutrition information panels (NIP) is complicated and difficult to understand, so that it becomes an obstacle in delivering accurate nutritional information for consumers. Nutrients-Rich Foods $\left(N R F_{n, 3}\right)$ Index provides an alternative to simplify NIP. In general, nutrient-rich foods are associated with high-priced products. This study aimed to analyze correlation between $N R F_{n, 3}$ index with nutrients fulfillment and price of products. NIP of dairy products and their analogues were used as research samples. The $N R F_{n, 3}$ index was determined using two calculation bases, $100 \mathrm{kcal}$ and $100 \mathrm{~g}$ of ready-to-consume products. $N R F_{12,3}$ index score in ready-to-drink $(R T D)$ milk and instant powdered milk positively correlated with the fulfillment of 11 nutrients to encourage. The average $N R F_{12,3}$ index score per $100 \mathrm{~g}$ of instant powdered milk was 91, higher than RTD milk which was only 76. As nutrient-dense foods, they had an index score of $N R F_{12,3}$ per $100 \mathrm{kcal}$ that was higher per $100 \mathrm{~g}$. Products with higher $N R F_{12,3}$ index scores tended to be marketed at higher price than that of lower ones.
\end{abstract}

Keywords: healthy diet, label, milk, nutrient-rich foods index, nutritional information panel

\begin{abstract}
Abstrak. Pengaturan pola makan sehat adalah salah satu upaya untuk mengurangi risiko penyakit tidak menular (PTM). Penggunaan bahasa ilmiah yang rumit dan sulit dipahami pada panel informasi nilai gizi (ING) menjadi hambatan untuk memberikan informasi gizi yang akurat kepada konsumen. Salah satu alternatif penyederhanaan ING adalah Indeks Nutrient-Rich Foods $\left(\mathrm{NRF}_{\mathrm{n}, 3}\right)$. Pada umumnya, pangan kaya gizi diasosiasikan dengan harga yang mahal. Penelitian ini bertujuan untuk menganalisis korelasi antara indeks $\mathrm{NRF}_{\mathrm{n}, 3}$ dengan tingkat pemenuhan zat gizi dan harga produk. Panel ING produk susu dan analognya digunakan sebagai sampel dalam penelitian ini. Indeks $\mathrm{NRF}_{\mathrm{n}, 3}$ dihitung dengan dua basis perhitungan, yaitu $100 \mathrm{kkal}$ dan $100 \mathrm{~g}$ produk dalam bentuk siap konsumsi. Skor indeks $\mathrm{NRF}_{12,3} \mathrm{RTD}$ susu UHT dan susu bubuk instan berkorelasi positif dengan tingkat pemenuhan 11 zat gizi yang dianjurkan. Susu bubuk instan rata-rata memiliki skor indeks $\mathrm{NRF}_{12,3}$ per $100 \mathrm{~g}$ sebesar 91 , lebih tinggi dari RTD susu UHT yang hanya 76 . Sebagai pangan padat gizi, keduanya memiliki skor indeks $\mathrm{NRF}_{12,3}$ per 100 kkal yang lebih tinggi dibandingkan skor indeks $\mathrm{NRF}_{12,3}$ per $100 \mathrm{~g}$. Produk dengan skor indeks $\mathrm{NRF}_{12,3}$ lebih tinggi cenderung dijual dengan harga yang lebih tinggi.
\end{abstract}

Kata kunci: diet sehat, indeks nutrient-rich foods, informasi nilai gizi, label, susu

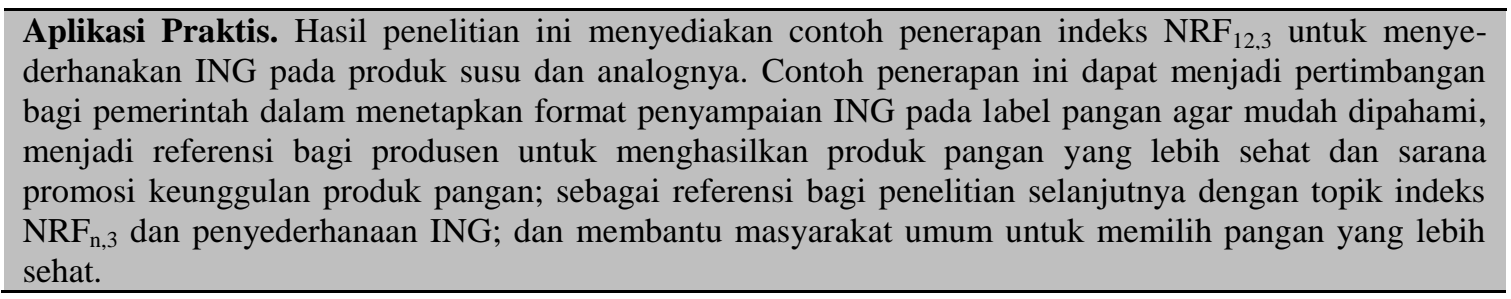

\section{PENDAHULUAN}

Penyakit tidak menular (PTM) saat ini menjadi penyebab terbesar kematian di Indonesia dan dunia. Berdasarkan laporan World Health Organization/WHO (2020), PTM merupakan penyebab $70 \%$ kematian di seluruh dunia dan $73 \%$ atau sekitar 1.365 .000 kematian di Indonesia pada tahun 2019. Kementerian Kesehatan

Korespondensi: hnpalupi@apps.ipb.ac.id
Republik Indonesia (2019) menyebutkan bahwa pada tahun 2017 sebanyak 10.801 .787 orang atau sekitar $5.7 \%$ peserta jaminan kesehatan nasional (JKN) mendapatkan pelayanan untuk penyakit katastropik dan menghabiskan biaya kesehatan sebesar 14.6 triliun rupiah atau $21.8 \%$ dari seluruh biaya pelayanan kesehatan pada tahun tersebut. Biaya kesehatan dengan komposisi peringkat pertama yaitu penyakit jantung sebesar $50.9 \%$ atau 7.4 triliun, diikuti penyakit ginjal kronik sebesar $17.7 \%$ atau 2.6 triliun rupiah. Menurut Inter- 
national Federation of Medical Students Associations (IFMSA 2018), terdapat empat faktor utama yang harus dikendalikan untuk menekan risiko PTM, antara lain konsumsi tembakau, konsumsi alkohol, aktifitas fisik, dan diet. Pengaturan asupan pangan yang baik merupakan salah satu upaya yang dapat dilakukan untuk mengurangi risiko PTM (WHO 2013).

Label pangan adalah setiap keterangan mengenai pangan yang berbentuk gambar, tulisan, kombinasi keduanya, atau bentuk lain yang disertakan pada pangan, dimasukkan ke dalam, ditempelkan pada, atau merupakan bagian dari kemasan pangan (BPOM 2016). Menurut Prinsloo et al. (2012), label pangan dapat memengaruhi keputusan pembelian produk pangan. Informasi gizi pada label pangan dapat menjadi metode paling efektif untuk mengkomunikasikan kandungan gizi dan keunggulan produk kepada konsumen. Pemerintah perlu mengeksplorasi format baru untuk memastikan bahwa informasi gizi dapat diakses dan dimengerti oleh konsumen (Campos et al. 2011).

Zafar et al. (2016) memaparkan bahwa sebagian konsumen tidak dapat memahami label pangan karena penggunaan bahasa ilmiah yang rumit dan sulit dipahami, terutama pada informasi nilai gizi (ING). Berdasarkan hasil penelitian Hieke et al. (2016), dari semua label produk yang mencantumkan klaim di Uni Eropa, mayoritas adalah klaim kandungan gizi, diikuti oleh klaim kesehatan, dan klaim bahan terkait kesehatan. Salah satu konsep penyederhanaan ING adalah Nutrient Profiling (NP). NP merupakan pendekatan kuantitatif untuk menilai kepadatan gizi pangan (Drewnowski 2017; Drewnowski dan Fulgoni 2014), yang merupakan pemeringkatan pangan menurut komposisi gizinya (Rayner et al. 2013).

NP awalnya dibuat untuk mencegah obesitas di negara maju, yaitu dengan memberikan peringkat lebih rendah untuk pangan yang mengandung kalori, lemak, gula, dan garam yang berlebihan. NP kemudian di konsep ulang agar dapat mengatasi kekurangan gizi dan defisiensi mikronutrien di negara berkembang (Drewnowski et al. 2021). NP dibuat untuk mengindentifikasi pangan kaya gizi dan memisahkannya dari pangan miskin gizi (Fulgoni et al. 2009). NP dapat menjadi dasar ilmiah untuk label front-of-pack (FoP), klaim kesehatan dan gizi (Julia et al. 2017), pengaturan pemasaran dan iklan untuk anak-anak (Rayner et al. 2013, Scarborough et al. 2013; Rayner 2017), dan reformulasi dalam industri pangan (Masset et al. 2016; Drewnowski 2017; Vlassopoulos et al. 2017). Menurut Chiuve et al. (2011), pelabelan yang disederhanakan, seperti FoP, dapat membantu konsumen memilih pangan yang lebih sehat. Salah satu NP yang sudah banyak diteliti adalah indeks Nutrient-Rich Foods (NRF).

Indeks NRF umumnya dihitung berdasarkan dua subskor, yaitu subskor Nutrient Rich $\left(\mathrm{NR}_{\mathrm{n}}\right)$ dan subskor Nutrient to Limit (LIM). $\mathrm{NR}_{\mathrm{n}}$ didasarkan pada sejumlah $\mathrm{n}$ variabel gizi yang dianjurkan, sedangkan LIM dihitung berdasarkan pada 3 nutrisi yang dibatasi (Drewnowski dan Fulgoni 2008, Fulgoni et al. 2009,
Drewnowski dan Fulgoni 2014). Indeks $\mathrm{NRF}_{\mathrm{n}, 3}$ merupakan metode penilaian produk pangan berdasarkan pemenuhan sejumlah $n$ zat gizi yang dianjurkan dan pemenuhan 3 zat gizi yang dibatasi (lemak jenuh, gula tambahan, dan natrium) dalam pangan tersebut (Drewnowski dan Fulgoni 2011). Penelitian terkait indeks $\mathrm{NRF}_{\mathrm{n}, 3}$ telah dilakukan di berbagai negara, antara lain: Amerika Serikat (Drewnowski 2005), Prancis (Darmon et al. 2005), Belanda (Sluik et al. 2015), Turki (Dikmen et al. 2015), Republik Ceko (Suchancova et al. 2015), dan Iran (Khankan et al. 2018). Di Indonesia penelitian terkait indeks $\mathrm{NRF}_{\mathrm{n}, 3}$ belum dilakukan.

Penggunaan bahasa ilmiah yang rumit dan sulit dipahami pada label pangan, serta adanya asosiasi kandungan gula, garam, lemak (GGL) yang tinggi dengan rasa yang enak, akan mempersulit upaya pemerintah dalam menekan risiko kematian akibat PTM yang terus meningkat dari tahun ke tahun. Oleh karena itu, diperlukan suatu inovasi dalam penyampaian ING yang tertera pada label pangan agar lebih mudah dipahami oleh masyarakat, sekaligus sebagai inovasi dalam penyampaian keunggulan produk yang lebih ringkas/sederhana sehingga dapat membantu pelaku usaha untuk mempromosikan produknya kepada masyarakat. Tujuan penelitian ini adalah menganalisis korelasi indeks $\mathrm{NRF}_{\mathrm{n}, 3}$ dengan tingkat pemenuhan zat gizi dan harga produk.

Hasil penelitian ini diharapkan dapat memberikan manfaat, antara lain: (1) sebagai bahan pertimbangan bagi pemerintah dalam menetapkan format penyampaian ING pada label pangan, (2) menjadi referensi bagi produsen untuk menghasilkan produk pangan yang lebih sehat dan sarana promosi keunggulan produk pangan, (3) sebagai referensi bagi penelitian selanjutnya dengan topik indeks $\mathrm{NRF}_{\mathrm{n}, 3}$ dan penyederhanaan ING, dan (4) membantu masyarakat umum untuk memilih pangan yang lebih sehat.

\section{BAHAN DAN METODE}

\section{Bahan}

Bahan yang digunakan dalam penelitian ini adalah ING yang tertera pada label produk pangan kategori susu dan analognya yang dipasarkan di pasar swalayan Top Brand 2020 di wilayah Jakarta, Depok, dan Tangerang. Kamera digital dan daftar produk (susu dan analognya) per Oktober 2020 yang diperoleh dari website BPOM (https:// cekbpom.pom.go.id) digunakan sebagai alat dalam penelitian ini.

\section{Pengumpulan data primer dan seleksi pre-sampel penelitian}

Observasi dilakukan dengan mengacu pada daftar produk susu dan analognya yang diperoleh dari website BPOM. Selama observasi, produk diseleksi berdasarkan kelengkapan ING minimum sesuai Peraturan BPOM RI (2019). Data yang dikumpulkan meliputi merek dagang, nomor izin edar, informasi nilai gizi, petunjuk konsumsi, dan harga. 
Penentuan model indeks $\mathrm{NRF}_{\mathrm{n}, 3}$ berdasarkan kelengkapan informasi nilai gizi (ING) dan seleksi sampel berdasarkan indeks $\mathbf{N R F}_{n, 3}$ terpilih

Model indeks $\mathrm{NRF}_{\mathrm{n}, 3}$ dipilih berdasarkan partisipasi pre-sampel, partisipasi zat gizi, dan besarnya nilai korelasi indeks $\mathrm{NRF}_{\mathrm{n}, 3}$ dengan pemenuhan zat gizi (\%AKG). Analisis korelasi Pearson dilakukan dengan teknik principal component analysis (PCA) menggunakan software XLSTAT ver 2021.2.1.1127. Sementara itu, pre-sampel diseleksi berdasarkan kelengkapan ING pada label untuk dapat dihitung menggunakan indeks $\mathrm{NRF}_{\mathrm{n}, 3}$ terpilih.

\section{Perhitungan skor indeks $\mathrm{NRF}_{\mathrm{n}, 3}$ dari sampel terpilih dan analisis korelasi}

Skor indeks $\mathrm{NRF}_{\mathrm{n}, 3}$ dihitung dengan basis $100 \mathrm{~g}$ (bentuk tersaji) dan $100 \mathrm{kkal}$ energi (Drewnowski 2017). Mengacu pada Drewnowksi (2017) serta Drewnowski dan Fulgoni (2020), skor indeks $\mathrm{NRF}_{\mathrm{n}, 3}$ secara sederhana ditentukan dengan rumus sebagai berikut:

Indeks $\mathrm{NRF}_{\mathrm{n}, 3}=$

$\sum \%$ AKG n gizi (dianjurkan) - $\sum \%$ AKG 3 gizi (dibatasi)..

dimana, $\mathrm{n}=$ zat gizi yang dianjurkan sesuai model profil gizi.

Ddi dalam penelitian ini, serat yang dihitung sebagai salah satu zat gizi yang dianjurkan adalah serat pangan (dietary fiber). Serat disubstitusi dengan serat pangan karena semua serat yang dicantumkan pada label produk susu dan analognya adalah serat pangan; 3 zat gizi yang dibatasi, yaitu: gula tambahan, natrium, dan lemak jenuh; Persentase AKG dihitung per $100 \mathrm{~g}$ produk dalam bentuk tersaji dan per $100 \mathrm{kkal}$ dengan nilai maksimum sebesar 100\%, yang jika lebih dari 100\% dihitung sebagai nilai maksimum (100\%).

Berat produk ready to drink (RTD) susu yang diproses dengan ultra high temperature (UHT) basis 100 $\mathrm{g}$ didapatkan dengan konversi volume $(\mathrm{mL})$ ke berat $(\mathrm{g})$ menggunakan berat jenis susu segar sesuai SNI 3141.1:2011 sebesar 1.027 g/mL. Produk susu bubuk instan basis $100 \mathrm{~g}$ dihitung dari bentuk produk yang sudah dilarutkan/ditambahkan air sesuai dengan saran penyajian yang dicantumkan pada label kemasan.

Analisis korelasi Pearson dilakukan dengan teknik PCA, yaitu dengan memeriksa ketergantungan/korelasi antara beberapa variabel, mencakup: (a) korelasi antara indeks $\mathrm{NRF}_{\mathrm{n}, 3}$ terpilih dan pemenuhan zat gizi $(\%$ AKG), (b) korelasi antara indeks $\mathrm{NRF}_{\mathrm{n}, 3}$ terpilih dan energi (kkal), serta (c) korelasi antara indeks $\mathrm{NRF}_{\mathrm{n}, 3}$ terpilih dan harga produk per $100 \mathrm{~g}$. Analisis PCA dilakukan menggunakan software XLSTAT 2021.2.1.11 27.

\section{HASIL DAN PEMBAHASAN}

\section{Model indeks $\mathrm{NRF}_{\mathrm{n}, 3}$ dan sampel terpilih}

Produk susu dan analognya yang terdaftar di website BPOM per Oktober 2020 sejumlah 4.917 produk, terdiri atas 3.674 terdaftar MD dan 1.243 terdaftar ML. Hasil seleksi berdasarkan Peraturan BPOM No. 22 Tahun 2019, diperoleh 382 produk sebagai pre-sampel penelitian. Data ING dari 382 produk kemudian ditabulasi menggunakan microsoft excel untuk melihat kelengkapan ING sebagai dasar perhitungan indeks $\mathrm{NRF}_{n, 3}$. Tabel 1 menunjukkan hasil partisipasi sampel menggunakan 10 model profil gizi yang dikombinasikan dengan tiga zat gizi yang dibatasi (LIM).

Penggunaan indeks $\mathrm{NRF}_{5,3}$ (NR5+LIM) dan indeks $\mathrm{NRF}_{6,3}$ (NR6+LIM) memiliki partisipasi sampel paling tinggi (64 sampel), dibandingkan dengan kombinasi 8 model profil gizi lainnya dengan LIM. Indeks $\mathrm{NRF}_{9 \mathrm{z}, 3}$ (NR9z+LIM) dan indeks NRF $_{12,3}$ (NR12+LIM) berada di urutan kedua dalam hal partisipasi sampel, yaitu 57 sampel. Partisipasi sampel paling rendah (0 sampel) diperoleh dari penggunaan indeks $\mathrm{NRF}_{14,3}(\mathrm{NR} 14+\mathrm{LIM})$ dan indeks $\mathrm{NRF}_{15,3}$ (NNR15+LIM).

Tabel 1. Jumlah sampel terpilih berdasarkan kombinasi beberapa model profil gizi dan tiga zat gizi yang dibatasi (LIM)

\begin{tabular}{|c|c|c|c|c|}
\hline No & $\begin{array}{l}\text { Model } \\
\text { Profil Gizi }\end{array}$ & Zat Gizi yang Dianjurkan & Referensi & $\begin{array}{c}\text { E Sampel } \\
\text { Terpilih* }\end{array}$ \\
\hline 1 & NR5 & Protein, serat, vit. C, Ca dan Fe & $\begin{array}{l}\text { AFSSA 2008, Drewnowski et al. } \\
\text { 2009b }\end{array}$ & 64 \\
\hline 2 & NR6 & Protein, serat, vit. C, vit. A, Ca dan Fe & Drewnowski dan Fulgoni 2008 & 64 \\
\hline 3 & NR9 & Protein, serat, vit. $\mathrm{C}$, vit. $\mathrm{A}$, vit. $\mathrm{E}, \mathrm{Ca}, \mathrm{Fe}, \mathrm{Mg}$ dan $\mathrm{K}$ & Drewnowski dan Fulgoni 2008 & 51 \\
\hline 4 & NR9z & Protein, serat, vit. C, vit. A, vit. E, $\mathrm{Ca}, \mathrm{Fe}, \mathrm{K}$ dan $\mathrm{Zn}$ & Drewnowski dan Fulgoni 2008 & 57 \\
\hline 5 & NR11 & Protein, serat, vit. $\mathrm{C}$, vit. $\mathrm{A}$, vit. $\mathrm{E}$, vit. $\mathrm{B}_{12}, \mathrm{Ca}, \mathrm{Fe}, \mathrm{Mg}, \mathrm{K}$ dan $\mathrm{Zn}$ & Drewnowski dan Fulgoni 2008 & 50 \\
\hline 6 & NR12 & $\begin{array}{l}\text { Protein, serat, vit. } C \text {, vit. } A \text {, vit. E, vit. } B_{12} \text {, vit. } B_{1} \text {, vit. } B_{2}, C a, F e \text {, } \\
\text { K dan Zn }\end{array}$ & Drewnowski dan Fulgoni 2008 & 57 \\
\hline 7 & NR14 & $\begin{array}{l}\text { Protein, MUFA, vit. } C \text {, vit. } A \text {, vit. } E \text {, vit. } B_{12} \text {, vit. } B_{1} \text {, vit. } B_{2} \text {, vit. } D_{3} \text {, } \\
\text { vit. } B_{9}, C a, F e, K \text { dan } Z n\end{array}$ & $\begin{array}{l}\text { Drewnowski dan Fulgoni 2008, } \\
\text { Drewnowski et al. 2009b }\end{array}$ & 0 \\
\hline 8 & NNR15 & $\begin{array}{l}\text { Protein, serat, MUFA, vit. } C \text {, vit. } A \text {, vit. } E \text {, vit. } B_{12} \text {, vit. } B_{1} \text {, vit. } B_{2} \text {, } \\
\text { vit. } D_{3} \text {, vit. } B_{9}, C a, F e, K \text { dan } Z n\end{array}$ & Drewnowski 2005 & 0 \\
\hline 9 & $\begin{array}{l}\text { NDS16 } \\
\text { AFSSA }\end{array}$ & $\begin{array}{l}\text { Protein, serat, linolenat, } \mathrm{DH} A \text {, vit. } C \text {, vit. } E \text {, vit. } B_{1} \text {, vit. } B_{2} \text {, vit. } \\
D_{3} \text {, vit. } B_{9} \text {, vit. } B_{6}, C a, F e, M g, K \text { dan } Z n\end{array}$ & $\begin{array}{l}\text { Darmon et al. } 2005 \\
\text { Drewnowski et al. } 2009 \mathrm{~b}\end{array}$ & 26 \\
\hline 10 & NDS23 & $\begin{array}{l}\text { Protein, serat, linolenat, } D H A \text {, linoleat, vit. } C \text {, vit. } A \text {, vit. } E \text {, vit. } \\
B_{12} \text {, vit. } B_{1} \text {, vit. } B_{2} \text {, vit. } D_{3} \text {, vit. } B_{9} \text {, vit. } B_{6} \text {, vit. } B_{3}, C a, F e, M g, K \text {, } \\
Z n, C u, S e \text {, dan I }\end{array}$ & Maillot et al. 2007 & 10 \\
\hline
\end{tabular}

Keterangan: *dipilih berdasarkan ketersediaan data zat gizi dari setiap model profil gizi dan zat gizi yang dibatasi (LIM). LIM mengacu Maillot et al. (2007) dan Fulgoni et al. (2009), terdiri atas: lemak jenuh, gula tambahan/gula total, dan natrium. Data serat yang digunakan dalam penelitian ini adalah serat pangan (dietary fiber) 
Selain pertimbangan partisipasi sampel dan zat gizi, kualitas korelasi antara indeks $\mathrm{NRF}_{\mathrm{n}, 3}$ dan pemenuhan zat gizi juga menjadi pertimbangan dalam pemilihan $\mathrm{NRF}_{\mathrm{n}, 3}$. Oleh karena itu, dilakukan analisis korelasi Pearson untuk empat indeks dengan partisipasi sampel terbanyak menggunakan teknik PCA. Adapun hasil analisis korelasi Pearson dapat dilihat pada Tabel 2.

Hasil analisis korelasi (Pearson) PCA empat model indeks $\mathrm{NRF}_{\mathrm{n}, 3}$ terhadap tingkat pemenuhan zat gizi menunjukkan indeks $\mathrm{NRF}_{12,3}$ memiliki rata-rata dan jumlah nilai korelasi positif lebih tinggi dibandingkan dengan tiga indeks $\mathrm{NRF}_{\mathrm{n}, 3}$ lainnya. Nilai korelasi positif yang lebih tinggi (mendekati nilai 1) menunjukkan tingkat korelasi positif yang semakin erat antar variabel yang diujikan dalam analisis PCA. Sebaliknya, nilai korelasi negatif yang lebih rendah (mendekati -1) menunjukkan tingkat korelasi negatif/berlawanan yang semakin erat antar variabel yang diujikan dalam analisis PCA. Berdasarkan partisipasi zat gizi yang dihitung, partisipasi sampel, dan hasil analisis korelasi (Pearson) PCA, indeks $\mathrm{NRF}_{12,3}$ dipilih sebagai indeks $\mathrm{NRF}_{n, 3}$ untuk produk susu dan analognya. Jumlah sampel dalam penelitian ini yang dapat dihitung menggunakan indeks $\mathrm{NRF}_{12,3}$ sejumlah 57 produk, terdiri atas 8 produk susu UHT full cream berperisa, 2 produk minuman mengandung susu berperisa, dan 47 produk susu bubuk instan. Berdasarkan pertimbangan jumlah sampel, serta untuk mempermudah analisis berikutnya, produk minuman mengandung susu berperisa dan produk susu UHT full cream berperisa digabung menjadi RTD susu UHT.

\section{Skor indeks $\mathrm{NRF}_{\mathbf{1 2 , 3}}$ produk susu dan analognya}

Indeks $\mathrm{NRF}_{12,3}$ dihitung dengan dua pendekatan, yaitu pendekatan per $100 \mathrm{~g}$ produk dan pendekatan per 100 kkal (Drewnowski 2017). Indeks $\mathrm{NRF}_{12,3}$ per $100 \mathrm{~g}$ produk susu dan analognya dapat dilihat pada Gambar 1, sementara untuk indeks $\mathrm{NRF}_{12,3}$ per $100 \mathrm{kkal}$ produk susu dan analognya dapat dilihat pada Gambar 2.

Tabel 2. Matriks korelasi indeks $\mathrm{NRF}_{\mathrm{n}, 3}$ dengan pemenuhan (\% AKG) zat gizi*

\begin{tabular}{|c|c|c|c|c|}
\hline Variabel & $\mathrm{NRF}_{5,3}$ & $\mathrm{NRF}_{6,3}$ & $\mathrm{NRF}_{9 \mathrm{~g}, 3}$ & $\mathrm{NRF}_{12,3}$ \\
\hline Protein (\% AKG) & 0.442 & 0.401 & 0.370 & 0.388 \\
\hline Serat pangan $(\% A K G)$ & 0.335 & 0.316 & 0.320 & 0.315 \\
\hline Vitamin C (\%AKG) & 0.645 & 0.610 & 0.548 & 0.506 \\
\hline Vitamin A (\% AKG) & 0.487 & 0.646 & 0.633 & 0.620 \\
\hline Vitamin $E$ (\% AKG) & 0.469 & 0.466 & 0.612 & 0.675 \\
\hline Vitamin $B_{12}(\% A K G)$ & 0.733 & 0.740 & 0.779 & 0.837 \\
\hline Vitamin $B_{1}(\% A K G)$ & 0.536 & 0.511 & 0.569 & 0.672 \\
\hline Vitamin $B_{2}(\% A K G)$ & 0.702 & 0.779 & 0.821 & 0.859 \\
\hline Kalsium (\% AKG) & 0.780 & 0.706 & 0.710 & 0.725 \\
\hline Zat besi (\% AKG) & 0.727 & 0.799 & 0.795 & 0.775 \\
\hline Kalium (\% AKG) & 0.045 & 0.058 & 0.143 & 0.259 \\
\hline Seng (\% AKG) & 0.637 & 0.662 & 0.740 & 0.683 \\
\hline Lemak jenuh (\% AKG) & -0.772 & -0.768 & -0.762 & -0.749 \\
\hline Gula total (\% AKG) & -0.444 & -0.391 & -0.411 & -0.384 \\
\hline Natrium (\% AKG) & -0.020 & -0.087 & -0.054 & -0.031 \\
\hline \multicolumn{5}{|c|}{ Nilai yang dicetak tebal berbeda dengan "0" dengan tingkat signifikansi alpha=0.05 } \\
\hline Rata-rata nilai korelasi positif & 0.590 & 0.603 & 0.627 & 0.641 \\
\hline Jumlah korelasi positif & 11 & 11 & 11 & 11 \\
\hline Jumlah nilai korelasi positif & 6.493 & 6.637 & 6.895 & 7.055 \\
\hline
\end{tabular}

Keterangan: * Principal Component Analysis (PCA) menggunakan XLSTAT versi 2021.2.1.1127

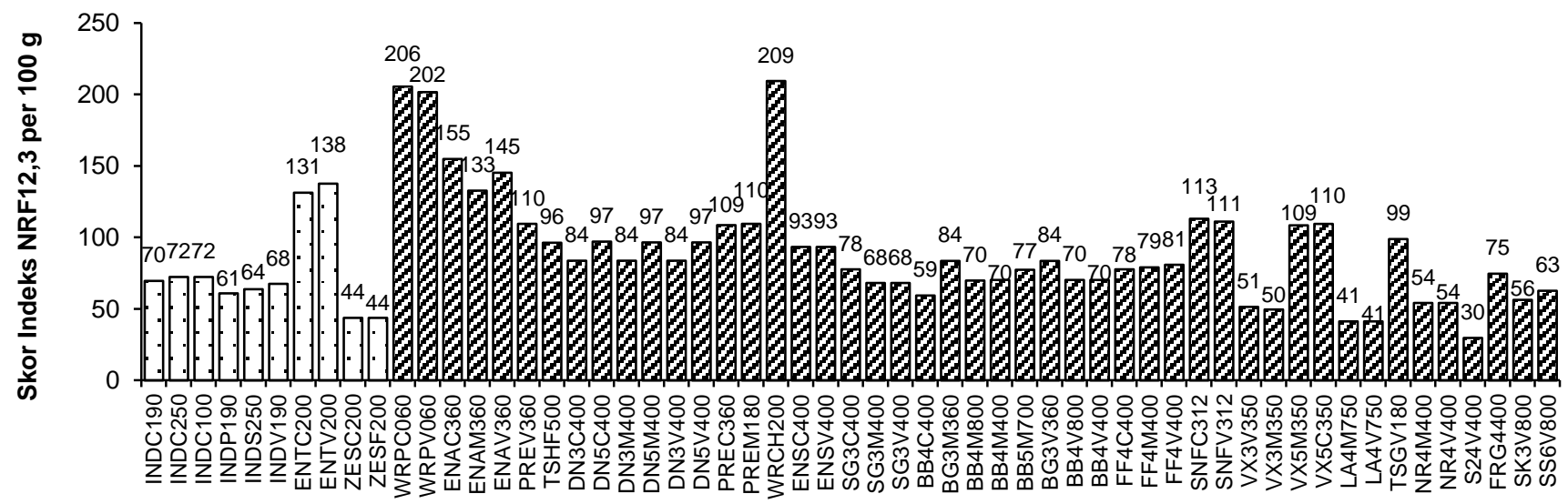

Sampel Produk Susu dan Analognya

: RTD Susu UHT

: Susu Bubuk Instan

Gambar 1. Skor indeks $\mathrm{NRF}_{12,3}$ per $100 \mathrm{~g}$ produk susu dan analognya 


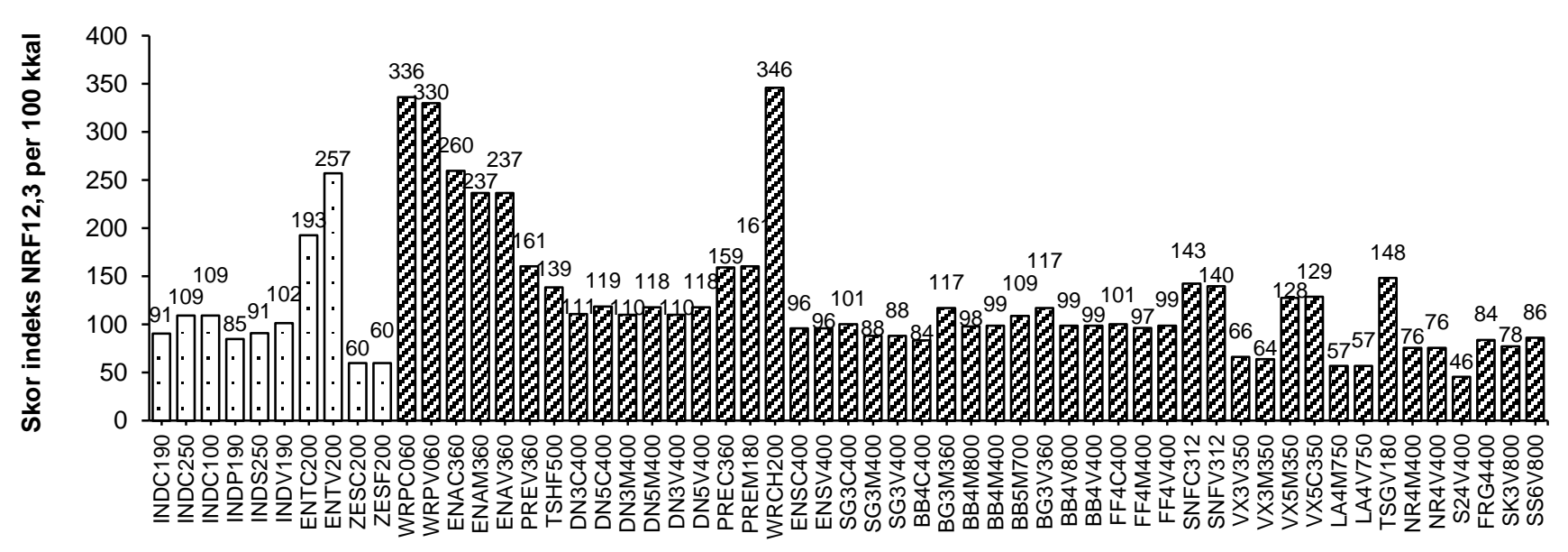

Sampel Produk Susu dan Analognya

RTD Susu UHT $\quad$ : Susu Bubuk Instan

Gambar 2. Skor indeks $\mathrm{NRF}_{12,3}$ per 100 kkal produk susu dan analognya

Rata-rata kelompok produk susu bubuk instan memiliki skor indeks $\mathrm{NRF}_{12,3}$ per $100 \mathrm{~g}$ lebih tinggi dibandingkan dengan RTD susu UHT. Produk susu bubuk instan memiliki rata-rata skor indeks $\mathrm{NRF}_{12,3}$ per $100 \mathrm{~g}$ sebesar 91, sedangkan produk RTD susu UHT memiliki rata-rata skor indeks $\mathrm{NRF}_{12,3}$ per $100 \mathrm{~g}$ sebesar 76. Skor indeks $\mathrm{NRF}_{12,3}$ per $100 \mathrm{~g}$ tertinggi diperoleh dari produk susu bubuk instan WRCH200 dengan skor 209, sementara skor indeks $\mathrm{NRF}_{12,3}$ per $100 \mathrm{~g}$ terendah diperoleh dari produk susu bubuk instan S24V400 dengan skor 30. Skor indeks $\mathrm{NRF}_{12,3}$ per $100 \mathrm{~g}$ RTD susu UHT bervariasi dari 44 (produk ZESC200 dan ZESF200) sampai dengan 138 (produk ENTV200). Meskipun rata-rata skor indeks $\mathrm{NRF}_{12,3}$ produk RTD susu UHT lebih rendah dibandingkan susu bubuk instan, terdapat dua produk RTD susu UHT yang memiliki skor indeks $\mathrm{NRF}_{12,3}$ melebihi rata-rata susu bubuk instan, yaitu ENTV200 dan ENTC200.

Pendekatan dengan perhitungan per $100 \mathrm{kkal}$ menghasilkan rata-rata skor indeks $\mathrm{NRF}_{12,3}$ susu bubuk instan yang masih tetap lebih unggul dibandingkan dengan RTD susu UHT. Susu bubuk instan memiliki rata-rata skor indeks $\mathrm{NRF}_{12,3}$ per $100 \mathrm{kkal}$ sebesar 128, sedangkan RTD susu UHT hanya memiliki rata-rata skor indeks $\mathrm{NRF}_{12,3}$ per $100 \mathrm{kkal}$ sebesar 116. Sama halnya dengan skor indeks $\mathrm{NRF}_{12,3}$ per $100 \mathrm{~g}$, skor indeks $\mathrm{NRF}_{12,3}$ per 100 kkal tertinggi diperoleh dari produk susu bubuk instan WRCH200 dengan nilai skor indeks 346 , sementara skor indeks $\mathrm{NRF}_{12,3}$ per 100 kkal terendah juga diperoleh dari produk yang sama, yaitu susu bubuk instan S24V400 dengan nilai skor indeks 46. Menurut Hess et al. (2017), produk susu dan analognya termasuk produk padat gizi, mengandung zat gizi yang dianjurkan dalam jumlah besar, namun zat gizi yang dibatasi relatif sedikit. Pangan padat gizi cenderung memiliki skor indeks $\mathrm{NRF}_{12,3}$ per $100 \mathrm{kkal}$ lebih tinggi dibandingkan skor indeks $\mathrm{NRF}_{12,3}$ per $100 \mathrm{~g}$ produk. Menurut Drewnowski (2017), secara sederhana pangan padat gizi didefinisikan sebagai pangan yang mengandung lebih banyak zat gizi daripada kalori, rendah lemak, rendah gula, dan rendah natrium. Kupirovi c ct al. (2019) memaparkan sebagian besar pangan di Slovenia yang diberi label dengan klaim kesehatan (mengacu Food Standards Australia New Zealand (FSANZ) nutrient profiling scoring criterion dan $\mathrm{WHO}$ Regional Office for Europe (WHOE) nutrient profile model) memiliki kualitas gizi yang buruk. Penilaian pangan dengan menggunakan model kepadatan gizi memberikan informasi tambahan tentang mutu pangan yang lebih baik dibandingkan penilaian dengan model padat energi (Sluik et al. 2015).

Gambar 3 menunjukkan posisi masing-masing sampel pada grafik skor indeks $\mathrm{NRF}_{12,3}$ per 100 kkal terhadap kepadatan energi (kkal/100 g). Produk WRCH200 menjadi produk yang paling padat nutrisi dibandingkan dengan 56 sampel produk susu lainnya. Produk ENSC 400 dan ENSV400 memiliki kecenderungan lebih padat energi dibandingkan dengan 55 sampel produk susu lainnya. Produk RTD susu UHT memiliki rata-rata kepadatan energi $68 \mathrm{kkal}$ per $100 \mathrm{~g}$, sementara produk susu bubuk instan memiliki rata-rata kepadatan energi lebih tinggi sebesar $74 \mathrm{kkal}$ per $100 \mathrm{~g}$. Perhitungan yang dilakukan Drewnowski (2018) dengan menggunakan data USDA Food and Nutrient Database for Dietary Studies (FNDDS 2009-2010), menunjukkan bahwa produk minuman mengandung susu berperisa dan rendah lemak memiliki kepadatan energi 68 kkal per 100 g. Kepadatan energi tersebut sama dengan rata-rata kepadatan energi produk RTD susu UHT dalam penelitian ini. Kepadatan energi susu bubuk instan lebih tinggi dibandingkan produk RTD susu UHT, yang salah satunya penyebabnya adalah kandungan protein susu bubuk instan lebih tinggi $1 \mathrm{~g} / 100 \mathrm{~g}$ produk dalam bentuk siap minum dibandingkan RTD susu UHT.

\section{Hubungan skor indeks $\mathrm{NRF}_{12,3}$ dengan tingkat peme- nuhan zat gizi (\% AKG) dan harga produk}

Tabel 3 menunjukkan perbandingan korelasi skor indeks $\mathrm{NRF}_{12,3}$ per $100 \mathrm{~g}$ dan skor indeks $\mathrm{NRF}_{12,3}$ per 100 kkal terhadap variabel pemenuhan zat gizi dan 
harga produk. Merujuk pada klasifikasi korelasi Sarwono (2006), indeks $\mathrm{NRF}_{12,3}$ per $100 \mathrm{~g}$ memiliki korelasi positif yang kuat/tinggi (>0.70-0.90) dengan pemenuhan vitamin $\mathrm{B}_{12}$, vitamin $\mathrm{B}_{2}$, kalsium, dan zat besi. Di sisi lain, indeks $\mathrm{NRF}_{12,3}$ per $100 \mathrm{kkal}$ memiliki korelasi positif yang kuat $(>0.70-0.90)$ dengan pemenuhan lebih banyak zat gizi yang dianjurkan, yaitu: vitamin $A$, vitamin $E$, vitamin $B_{12}$, vitamin $B_{1}$, vitamin $\mathrm{B}_{2}$, kalsium, zat besi, dan seng. Kedua pendekatan, baik per $100 \mathrm{~g}$ maupun per $100 \mathrm{kkal}$, menunjukkan korelasi negatif yang kuat dengan pemenuhan lemak jenuh. Penelitian Sluik et al. (2015) menunjukkan adanya korelasi positif antara skor $\mathrm{NR}_{\mathrm{n}}$ (NR6-NR20) dengan skor indeks $\mathrm{NRF}_{\mathrm{n}, 3}$, mulai dari 0.76 sampai dengan 0.99, tetapi terdapat korelasi negatif (berbanding terbalik) antara LIM atau zat gizi yang dibatasi dengan skor indeks $\mathrm{NRF}_{\mathrm{n}, 3}$, mulai dari -0.05 pada penggunaan indeks $\mathrm{NRF}_{18,3}$ sampai dengan - 0.27 pada penggunaan indeks $\mathrm{NRF}_{6,3}$.

Tabel 3. Perbandingan nilai korelasi skor indeks $\mathrm{NRF}_{12,3}$ per $100 \mathrm{~g}$ dan skor indeks $\mathrm{NRF}_{12,3}$ per $100 \mathrm{kkal}$ terha-dap variabel pemenuhan zat gizi dan harga produk

\begin{tabular}{|c|c|c|}
\hline \multirow{2}{*}{ Variabel } & \multicolumn{2}{|c|}{ Indeks NRF $_{12,3}$} \\
\hline & Per $100 \mathrm{~g}$ & Per 100 kkal \\
\hline Protein (\% AKG) & 0.388 & 0.589 \\
\hline Serat pangan (\% AKG) & 0.315 & 0.364 \\
\hline Vitamin C (\%AKG) & 0.506 & 0.599 \\
\hline Vitamin A (\% AKG) & 0.620 & 0.720 \\
\hline Vitamin E (\% AKG) & 0.675 & 0.774 \\
\hline Vitamin $B_{12}(\%$ AKG) & 0.837 & 0.890 \\
\hline Vitamin $B_{1}(\% A K G)$ & 0.672 & 0.757 \\
\hline Vitamin $B_{2}(\% A K G)$ & 0.859 & 0.900 \\
\hline Kalsium (\% AKG) & 0.725 & 0.790 \\
\hline Zat besi (\% AKG) & 0.775 & 0.798 \\
\hline Kalium (\% AKG) & 0.259 & 0.487 \\
\hline Seng $(\% A K G)$ & 0.683 & 0.772 \\
\hline Lemak jenuh (\% AKG) & -0.749 & -0.712 \\
\hline Gula total (\% AKG) & -0.384 & -0.202 \\
\hline Natrium (\% AKG) & -0.031 & 0.103 \\
\hline Harga (Rp) & 0.342 & 0.515 \\
\hline
\end{tabular}

Keterangan: Nilai yang dicetak tebal berbeda dengan "0" dengan tingkat signifikansi alpha $=0.05$
Harga produk memiliki korelasi positif dengan kedua pendekatan, yaitu korelasi rendah dengan $\mathrm{NRF}_{12,3}$ per $100 \mathrm{~g}$ dan moderat dengan $\mathrm{NRF}_{12,3}$ per 100 kkal. Drewnowski (2010) menyebutkan bahwa model profil gizi, dalam hal ini indeks NRF, memungkinkan konsumen untuk mengidentifikasi pangan yang menyediakan zat gizi optimal bagi tubuh dengan biaya/harga terjangkau.

Indeks $\mathrm{NRF}_{12,3}$ per $100 \mathrm{kkal}$ pada produk susu dan analognya lebih unggul dibandingkan dengan indeks $\mathrm{NRF}_{12,3}$ per $100 \mathrm{~g}$ dalam hal korelasinya terhadap pemenuhan zat gizi yang dianjurkan, baik dari segi jumlah zat gizi yang berkorelasi (12 zat gizi, ada tambahan kalium) maupun dari kualitas korelasinya. Merujuk penelitian Drewnowski et al. (2009a), skor kepadatan gizi/ Nutrient-Rich $\left(\mathrm{NR}_{6}\right)$ per $100 \mathrm{kkal}$ memiliki koefisien korelasi Spearman dengan $\mathrm{NR}_{6}$ per FDA Reference Amounts Customarily Consumed (RACC) sebesar 76\%, lebih besar dibandingkan koefisien korelasi Spearman antara $\mathrm{NR}_{6}$ per $100 \mathrm{~g}$ dengan $\mathrm{NR}_{6}$ per $\mathrm{RACC}$ yang hanya $63 \%$. Hal ini menunjukkan bahwa pendekatan per 100 kkal lebih sebanding dengan pendekatan menggunakan jumlah/takaran yang biasa/normal dikonsumsi (RACC).

Di sisi lain, penggunaan indeks $\mathrm{NRF}_{12,3}$ per $100 \mathrm{~g}$ pada produk susu dan analognya lebih unggul dibandingkan dengan indeks $\mathrm{NRF}_{12,3}$ per 100 kkal dalam hal korelasinya terhadap pemenuhan zat gizi yang dibatasi dari segi jumlah zat gizi yang berkorelasi ( 2 zat gizi, ada tambahan gula total). Menurut Drewnowski (2017), penggunaan indeks $\mathrm{NRF}_{\mathrm{n}, 3}$ per $100 \mathrm{kkal}$ lebih cocok untuk meningkatkan pemenuhan zat gizi yang dianjurkan atau digunakan pada pangan padat gizi, sedangkan indeks $\mathrm{NRF}_{\mathrm{n}, 3}$ per $100 \mathrm{~g}$ lebih cocok untuk menurunkan pemenuhan zat gizi yang dibatasi atau digunakan pada pangan padat energi. Meskipun demikian, pendekatan indeks $\mathrm{NRF}_{\mathrm{n}, 3}$ menggunakan basis perhitungan $100 \mathrm{kkal}$ dinilai lebih baik untuk menghindari penggabungan kepadatan energi dan kepadatan gizi (Drewnowski dan Fulgoni 2020).

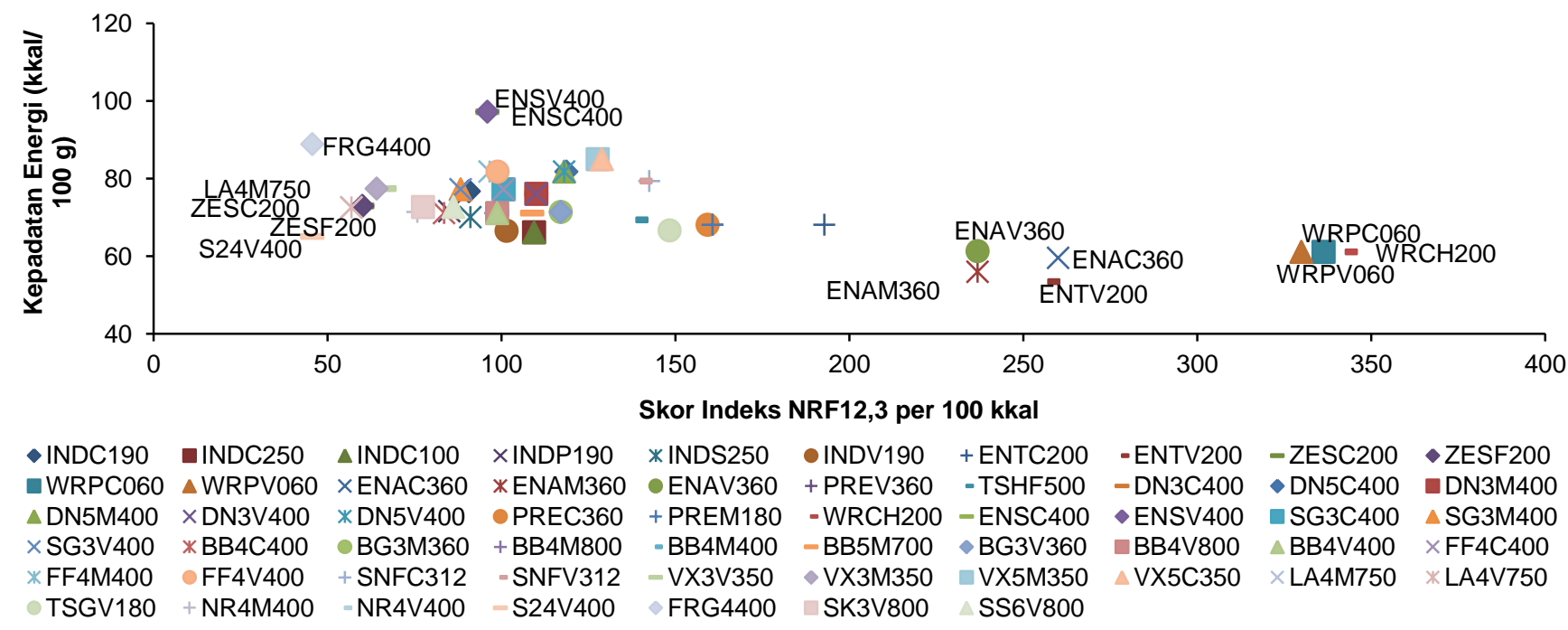

Gambar 3. Skor indeks $\mathrm{NRF}_{12,3}$ per 100 kkal dari 57 sampel produk susu dan analognya yang diplotkan terhadap kepadatan energi (kkal/100 g) 
Penggunaan indeks $\mathrm{NRF}_{12,3}$ memberikan gambaran alternatif penyederhanaan ING pada label pangan olahan. Pemerintah dapat mengkaji penggunaan indeks $\mathrm{NRF}_{\mathrm{n}, 3}$ sebagai alternatif format penyampaian ING pada label pangan sesuai dengan kebutuhan dan tujuan yang diharapkan, yaitu menggunakan pendekatan per $100 \mathrm{~g}$ untuk memperbaiki gizi buruk, atau menggunakan pendekatan per 100 kkal untuk mengurangi konsumsi gula, garam, dan lemak (GGL). Produsen dapat menjadikan indeks $\mathrm{NRF}_{n, 3}$ sebagai referensi untuk menghasilkan produk pangan yang lebih sehat sekaligus sebagai sarana promosi keunggulan produk pangan melalui label pangan. Penggunaan indeks $\mathrm{NRF}_{\mathrm{n}, 3}$ untuk menyederhanakan ING secara kuantitatif diharapkan membantu masyarakat umum untuk membandingkan dan memilih pangan yang lebih sehat dengan harga yang lebih kompetitif sesuai kemampuan ekonomi mereka.

\section{KESIMPULAN}

Skor indeks $\mathrm{NRF}_{12,3}$ dapat digunakan untuk menyederhanakan ING pada label produk susu dan analognya. Skor indeks $\mathrm{NRF}_{12,3}$, baik dengan pendekatan per $100 \mathrm{~g}$ maupun per $100 \mathrm{kkal}$, memiliki korelasi positif dengan tingkat pemenuhan 11 zat gizi yang dianjurkan, dan memiliki korelasi negatif dengan tingkat pemenuhan lemak jenuh. Skor indeks $\mathrm{NRF}_{12,3}$ semakin meningkat dengan semakin tingginya tingkat pemenuhan protein, serat pangan, vitamin $\mathrm{C}$, vitamin $\mathrm{A}$, vitamin $\mathrm{E}$, vitamin $B_{12}$, vitamin $B_{1}$, vitamin $B_{2}$, kalsium, zat besi, dan seng, serta rendahnya tingkat pemenuhan lemak jenuh. Khususnya pada pendekatan per $100 \mathrm{~g}$, skor indeks $\mathrm{NRF}_{12,3}$ juga cenderung lebih tinggi dengan rendahnya tingkat pemenuhan gula total. Harga produk berkorelasi positif dengan skor indeks $\mathrm{NRF}_{12,3}$. Produk yang memiliki skor indeks $\mathrm{NRF}_{12,3}$ lebih tinggi cenderung dipasarkan dengan harga per $100 \mathrm{~g}$ maupun per 100 kkal yang juga lebih tinggi. Berdasarkan hasil analisis korelasi dengan tingkat pemenuhan zat gizi, penggunaan indeks $\mathrm{NRF}_{12,3}$ per $100 \mathrm{kkal}$ lebih sesuai untuk meningkatkan pemenuhan zat gizi yang dianjurkan, sedangkan penggunaan indeks $\mathrm{NRF}_{12,3}$ per $100 \mathrm{~g}$ lebih sesuai untuk mengurangi konsumsi zat gizi yang dibatasi.

\section{DAFTAR PUSTAKA}

[AFSSA] Agence Française de Sécurité Sanitaire des Aliments. 2008. Setting of nutrient profiles for accessing nutrition and health claims: proposals and arguments. https://www.anses.fr/en/system/files/ NUT-Ra-ProfilsEN.pdf.

[BPOM RI] Badan Pengawas Obat dan dan Makanan Republik Indonesia. 2016. Peraturan Kepala Badan Pengawas Obat dan Makanan Republik Indonesia Nomor 13 Tahun 2016 tentang Pengawasan Klaim pada Label dan Iklan Pangan Olahan. Jakarta (ID): BPOM RI.

[BPOM RI] Badan Pengawas Obat dan Makanan Republik Indonesia. 2019. Peraturan Kepala Badan Pengawas Obat dan Makanan Republik Indonesia Nomor 22 Tahun 2019 tentang Informasi Nilai Gizi pada Label Pangan Olahan. Jakarta (ID): BPOM RI.

Campos S, Doxey J, Hammond D. 2011. Nutrition labels on pre-packaged foods: a systematic review. Public Health Nutr 14 (8): 1496-1506. DOI: 10. 1017/ S1368980010003290.

Chiuve SE, Sampson L, Willett WC. 2011. The association between anutritional quality index and risk of total chronic disease. Am J Prev Med 40 (5): 505513. DOI: 10.1016/j.amepre.2010.11.022.

Darmon N, Darmon M, Maillot M, Drewnowski A. 2005. A nutrient density standard for vegetables and fruits: nutrients per calorie and nutrients per unit cost. J Am Diet Assoc 105(12): 1881-1887. DOI: 10.1016/j.jada. 2005.09.005.

Dikmen D, Kizil M, Uyar MF, Pekcan G. 2015. Testing two nutrient profiling models of labeled foods and beverages marketed in Turkey. Cent Eur J Publ Heal 23(2): 155-160. DOI: 10.21101/cejph.a3992.

Drewnowski A. 2005. Concept of a nutritious food: Toward a nutrient density score. Am J Clin Nutr 82(4): 721-732. DOI: 10.1093/ajcn/82.4.721.

Drewnowski A. 2010. The nutrient rich foods index helps to identify healthy, affordable foods. Am J Clin Nutr 91(4): 1095S-1101S. DOI: 10.3945/ajen. 2010.28450D.

Drewnowski A. 2017. Uses of nutrient profiling to address public health needs: From regulation to reformulation. P Nutr Soc 76(3): 220-229. DOI: 10. 1017/S0029665117000416.

Drewnowski A. 2018. Nutrient density: addressing the challenge of obesity. Brit J Nutr 120(S1): S8-S14. DOI: $10.1017 /$ S0007114517002240.

Drewnowski A, Amanquah D, Smith BG. 2021. Perspective: How to develop nutrient profiling models intended for global use: a manual. Adv Nutr 12(3): 609-620. DOI: 10.1093/advances/nmab018.

Drewnowski A, Fulgoni V, III. 2008. Nutrient profiling of foods: Creating a nutrient-rich food index. Nutr Rev 66(1): 23-39. DOI: 10.1111/j.1753-4887.2007. 00003.x.

Drewnowski A, Fulgoni V, III. 2011. Comparing the nutrient rich foods index with "go," "slow," and "whoa" foods. J Am Diet Assoc 111(2): 280-284. DOI: $10.1016 /$ j.jada.2010.10.045.

Drewnowski A, Fulgoni VL. 2014. Nutrient density: Prin-ciples and evaluation tools. Am J Clin Nutr 99(5): 1223S-1228S. DOI: 10.3945/ajen.113.0733 95. 
Drewnowski A, Fulgoni VL III. 2020. New nutrient rich food nutrient density models that include nutrients and myplate food groups. Front Nutr 7(2020): 107. DOI: $10.3389 /$ fnut.2020.00107.

Drewnowski A, Maillot M, Darmon N. 2009a. Should nutrient profiles be based on $100 \mathrm{~g}, 100 \mathrm{kcal}$ or serving size?. Eur J Clin Nutr 63(2009): 898-904. DOI: 10.1038/ejen.2008.53.

Drewnowski A, Maillot M, Darmon N. 2009b. Testing nutrient profile models in relation to energy density and energy cost. Eur J Clin Nutr 63(2009): 674-683. DOI: 10.1038/ejcn.2008.16.

[FSANZ] Food Standards Australia New Zealand. 2017. Australia New Zealand Food Standards Code: Schedule 5 - Nutrient profiling scoring method. In Food Standards Gazette, F2017C00318. Canberra (AU): FANZ.

Fulgoni VL, Keast DR, Drewnowski A. 2009. Development and validation of the Nutrient-Rich Foods index: a tool to measure nutritional quality of foods. J Nutr 139(8): 1549-1554. DOI: 10.3945/jn.108. 101360 .

Hess J, Rao G, Slavin J. 2017. The nutrient density of snacks: a comparison of nutrient profiles of popular snack foods using the nutrient-rich foods index. Glob Pediatr Heal 4(2017): 1-6. DOI: 10.1177/ $2333794 X 17698525$.

Hieke S, Kuljanic N, Pravst I, Miklavec K, Kaur A, Brown KA, Egan BM, Pfeifer K, Gracia A, Rayner M. 2016. Prevalence of nutrition and health-related claims on pre-packaged foods: A five-country study in Europe. Nutrients 8 (3): 137. DOI: $10.3390 / \mathrm{nu}$ 8030137.

[IFMSA] International Federation of Medical Students Associations. 2018. Noncommunicable Diseases and the Most Common Shared Risk Factor. Amsterdam (NL): IFMSA.

Julia C, Péneau S, Buscail C, Gonzalez R, Touvier M, Hercberg S. 2017. Perception of different formats of front-of-pack nutrition labels according to sociodemographic, lifestyle and dietary factors in a French population: crosssectional study among the NutriNet-Santé cohort participants. BMJ Open 7(6): e016108. DOI: 10.1136/bmjopen-2017-016108.

[Kemenkes RI] Kementerian Kesehatan Republik Indonesia. 2019. Buku Pedoman Manajemen Penyakit Tidak Menular. Jakarta (ID): Direktorat Pencegahan dan Pengendalian Penyakit Tidak Menular Kementerian Kesehatan.

Khankan J, Jazayeri S, Shidfar F, Hezaveh ZS, Hosseini AF, Vafa MR. 2018. The relationship between nutrient-rich foods (NRF) index as a measure of diet quality and malnutrition in children. J Nutr Food Secur 4(1): 34-42. DOI: 10.18502/jnfs.v4i1.398.
Kupirovǐc UP, Miklavec K, Hribar M, Kušar A, Žmitek K, Pravst I. 2019. Nutrient profiling is needed to improve the nutritional quality of the foods labelled with health-related claims. Nutrients 11(2): 287. DOI: $10.3390 / \mathrm{nu} 11020287$.

Maillot M, Darmon N, Darmon M, Lafay L, Drewnowski A. 2007. Nutrient-dense food groups have high energy costs: An econometric approach to nutrient profiling. J Nutr 137(7): 1815-1820. DOI: 10.1093/jn/137.7.1815.

Masset G, Mathias KC, Vlassopoulos A, Mölenberg F, Lehmann U, Gibney M. 2016. Modeled dietary impact of pizza reformulations in US children and adoles-cents. PLoS ONE 11(10): e0164197. DOI: 10.1371/journal.pone.0164197.

Prinsloo N, van der Merwe D, Bosman M, Erasmus A. 2012. A critical review of the significance of food la-belling during consumer decision making. J Fam Ecol Consum Sci 40(2012): 83-98.

Rayner M. 2017. Nutrient profiling for regulatory purposes. Proc Nutr Soc 76(3): 230-236. DOI: 10. 1017/ S0029665117000362.

Rayner M, Scarborough P, Kaur A. 2013. Nutrient profiling and the regulation of marketing to children: Possibilities and pitfalls. Appetite 62: 232235. DOI: 10.1016/j.appet.2012.06.021.

Sarwono J. 2006. Metode Penelitian Kuantitatif dan Kualitatif. Graha Ilmu, Yogyakarta.

Scarborough P, Payne C, Agu CG, Kaur A, Mizdrak A, Rayner M, Halford JCG, Boyland E. 2013. How important is the choice of the nutrient profile model used to regulate broadcast advertising of foods to children? a comparison using a targeted data set. Eur J Clin Nutr 67: 815-820. DOI: 10.1038/ejcn. 2013.112.

Sluik D, Streppel MT, Lee L, Geelen A, Feskens EJM. 2015. Evaluation of a nutrient-rich food index score in the Netherlands. J Nutr Sci 4 (e14): 1-9. DOI: 10.10 17/jns.2015.4.

Suchancova M, Kapounova Z, Dofkova M, Ruprich J, Blahova J, Kourilova I. 2015. Selected fruits and vegetables: Comparison of nutritional value and affordability. Czech J Food Sci 33(3): 242-246. DOI: 10.17221/353/2014-CJFS.

[USDA] U.S. Department of Agriculture, Agricultural Research Service. 2012. Total Nutrient Intakes: Percent Reporting and Mean Amounts of Selected Vitamins and Minerals from Food and Dietary Supplements, by Family Income (as \% of Federal Poverty Threshold) and Age, What We Eat in America, NHANES 2009-2010. www.ars.usda.gov/ ba/bhnrc/fsrg. 
Vlassopoulos A, Masset G, Charles VR, Hoover C, Chesneau-Guillemont C, Leroy F. 2017. A nutrient profiling system for the (re)formulation of a global food and beverage portfolio. Eur J Nutr 56: 110522. DOI: 10.1007/s00394-016-1161-9.

[WHO] World Health Organization. 2013. Global Action Plan for The Prevention and Control of Noncommunicable Diseases 2013-2020. Geneva (CH): WHO.
[WHO] World Health Organization. 2020. Noncommunicable Diseases Progress Monitor 2020. Geneva (CH): WHO.

Zafar MZ, Hashim NA, Halim F. 2016. Food label makes individual healthy. J Sci Res Dev 3(1): 6876.

JMP-06-21-04-Naskah diterima untuk ditelaah pada 6 Februari 2021. Revisi makalah disetujui untuk dipublikasi pada 1 April 2021. Versi Online: http://journal.ipb.ac.id/index.php/jmpi 